\title{
Pengaruh Iklim Organisasi, Komitmen Karyawan, dan Kepuasan Kerja Terhadap Prestasi Kerja Karyawan PT. XL Axiata Padang
}

\author{
M. Afuan \\ Fakultas Ekonomi Universitas Putra Indonesia YPTK Padang \\ m.afuan311@gmail.com
}

\begin{abstract}
Abstrak
Penelitian ini bertujuan untuk mengungkapkan, (1) Pengaruh Iklim Organisasi Terhadap Prestasi Kerja Karyawan,(2) Komitmen Karyawan Terhadap Prestasi Kerja Karyawan, (3) Kepuasan Kerja Terhadap Prestasi Kerja Karyawan, (4) Pengaruh Iklim Organisasi, Komitmen Karyawan, dan Kepuasan Kerja secara bersama-sama terhadap Prestasi Kerja Karyawan. Populasi dalam penelitian ini adalah Karyawan PT. XL Axiata Padang yang berjumlah 80 orang, dimana teknik pengambilan sampel adalah secara Total Population. Penelitian ini dilakukan dengan menggunakan pendekatan survey. Pendekatan survey adalah kegiatan mengumpulkan data sebanyak banyaknya mengenai fakta-fakta yang merupakan pendukung terhadap penelitian, dengan maksud untuk mengetahui status dan gejala. Kesimpulan dari penelitian bahwa pengaruh Iklim Organisasi, Komitmen Karyawan dan Kepuasan Kerja, terhadap Prestasi Kerja Karyawan baik secara parsial maupun secara simultan terbukti/ diterima dalam penelitian ini.
\end{abstract}

Kata kunci : Iklim Organisasi, Komitmen Karyawan, Kepuasan Kerja, Prestasi Kerja Karyawan.

\section{Pendahuluan}

Dalam suasana persaingan bisnis saat ini, sumber daya manusia (SDM) di dalam perusahaan harus mampu untuk menjadi mitra kerja yang dapat diandalkan,baik oleh para pimpinan puncak perusahaan, maupun manajer lini. Para manajer SDM saat ini berada dalam tekanan yang tinggi untuk menjadi mitra bisnis strategis, yaitu berperan dalam membantu organisasi untuk memberikan tanggapan terhadap tantangan-tantangan yang berkaitan dengan down-sizing, restrukturisasi, dan persaingan global dengan memberikan kontribusi yang bernilai tambah bagi keberhasilan bisnis. Sehubungan dengan hal tersebut dalam beberapa tahun terakhir ini, para manajer perusahaan semakin banyak mengarahkan perhatiannya pada perilaku organisasi (organizational behaviors) baik pada tingkatan manajer level atas maupun pekerja atau karyawan secara keseluruhan. Tujuannya adalah untuk meningkatkan profesionalitas yang berorientasi pada keunggulan kompetitif untuk memenangkan setiap persaingan yang ada (Gitosudarmo dan Sudita, 2005.

Untuk mencapai tingkat keunggulan bersaing yang tinggi dan berkesinambungan, sebuah organisasi lebih menekankan pada pengelolaan sumber daya manusia yang ada. Meskipun demikian, pengelolaan sumber daya manusia juga tidak hanya menekankan pada efisiensi serta efektivitas organisasi saja, tetapi juga menekankan pada tataran nilai-nilai individu. Hal tersebut menjadi salah satu elemen pokok dalam organisasi yaitu kesediaan dan kemauan para karyawan untuk memberikan daya upaya mereka secara nyata pada pencapaian tujuan organisasi secara menyeluruh.

Prestasi kerja karyawan berhubungan dengan faktor di dalam perusahaan, seperti Iklim Organisasi dan kepuasan kerja. Iklim Organisasi dapat menciptakan suasana yang menyenangkan atau tidak menyenangkan bagi orang-orang yang ada dalam organisasi. Kondisi ini selanjutnya akan mempengaruhi prestasi kerja karyawan. Meskipun suatu organisasi mempunyai karyawan yang handal, jika tidak didukung dengan Iklim Organisasi yang kondusif, maka akan menghambat prestasi kerja karyawan yang selanjutnya akan berdampak terhadap keberhasilan organisasi (Mangkunegara, 2009).

Prestasi kerja karyawan tidak hanya berhubungan dengan faktor di dalam perusahaan, tetapi juga faktor di dalam diri karyawan itu sendiri, diantaranya komitmen. Komitmen yang tinggi akan meningkatkan prestasi kerja karyawan. Pengertian komitmen saat ini, tidak lagi sekedar berbentuk kesediaan karyawab 
bekerja di perusahaan itu dalam jangka waktu lama. Namun lebih penting dari itu, karyawan mau memberikan yang terbaik kepada perusahaan, bahkan bersedia mengerjakan lebih dari yang ditargetkan perusahaan. Hal ini hanya bisa terjadi jika karyawan merasa senang dan terpuaskan di perusahaan yang bersangkutan. Banyak faktor yang mempengaruhi komitmen seseorang terhadap organisasi, diantaranya adalah masa kerja, karakteristik pribadi, dan faktor Iklim Organisasi. Semakin lama seseorang bekerja pada suatu organisasi maka komitmennya terhadap organisasi juga semakin baik. Karakteristik pribadi yang berhubungan dengan komitmen seperti tingkat pendidikan, jenis kelamin dan juga perannya di dalam organisasi. Selanjutnya Iklim Organisasi yang kondusif akan meningkatkan komitmen karyawan terhadap perusahaan.

Untuk mempertahankan dan meningkatkan produktivitas perusahaan, tentu saja berbagai pihak yang terkait dengan perusahaan harus memperhatikan tingkat kepuasan kerja sekaligus prestasi kerja karyawannya. Tingkat kepuasan kerja tidak terlepas dari pengaruh kondisi Iklim Organisasi yang berlaku. Pelaksanaan pekerjaan dalam perusahaan adalah berdasarkan target, dimana perusahaan memberikan reward berdasarkan pencapaian target, namun karyawan sering merasa bahwa reward yang diberikan perusahaan tidak sebanding dengan prestasi yang dicapainya. Hal ini mempengaruhi kepuasan kerja karyawan, yang selanjutnya akan mempengaruhi prestasi kerja karyawan. Selain itu, hubungan langsung dan komunikasi dengan atasan juga berpengaruh terhadap terciptanya Iklim Organisasi yang kondusif (Marwansyah dan Mukaram, 2000).

Perasaan senang dan terpuaskan juga diperoleh dari perlakuan yang diterimanya dari perusahaan serta hubungan timbal balik antara karyawan dan perusahaan sehingga karyawan merasa bertanggung jawab dan merasa memiliki terhadap perusahaan. Gejala yang sering terjadi dalam sebuah organisasi sebagai akibat dari kurang stabilnya organisasi adalah rendahnya tingkat kepuasan kerja dan prestasi kerja yang dicapai olehkaryawan. Akibat paling ekstrim yang dapat ditimbulkan oleh ketiga hal tersebut adalah terjadinya pemogokan, kelambanan, kemangkiran, dan tingkat pengunduran diri karyawan yang cukup tinggi.

Sehubungan dengan penjelasan di atas, dilakukan suatu kajian pada salah satu perusahaan swasta yang bergerak di bidang telekomunikasi yang menyediakan jaringan komunikasi yang handal di Indonesia, yaitu PT. XL Axiata Regional Sumatera di Padang XL Axiata (sebelumnya bernama PT. Excelcomindo Pratama) pada saat ini merupakan penyedia layanan telekomunikasi seluler dengan cakupan jaringan yang luas di seluruh wilayah Indonesia layanan telekomunikasi seluler yang menjadi pesaing dari PT. XL Axiata. bagi pelanggan ritel dan menyediakan solusi bisnis bagi pelanggan korporat. Layanan PT. XL Axiata mencakup antara lain percakapan, data dan layanan nilai tambah lainnya (value added services). Di Indonesia terdapat beberapa perusahaan penyedia.

Berdasarkan survey tahap awal, diperoleh informasi bahwa, PT. XL Axiata Regional Sumatera mempunyai karyawan sebanyak 139 orang yang terdiri dari karyawan tetap maupun karyawan tidak tetap. Fenomena prestasi kerja karyawan diantaranya dapat dilihat dari pemenuhan permohonan aktivasi pasca bayar yang hanya mencapai $92 \%$ dan pemenuhan aktivasi pra bayar mencapai $87 \%$ dari target $100 \%$. Hal ini berhubungan dengan faktor Iklim Organisasi, kepuasan kerja dan komitmen karyawan. Dalam hal Iklim Organisasi, masih kurang kondusif bagi sebagian karyawan yang disebabkan kesempatan promosi yang berbeda kepada karyawan. Hal ini menyebabkan mereka tidak bekerja secara maksimal, dan adanya keinginan karyawan untuk mencari pekerjaan lain dan pindah dari perusahaan. Demikian juga dalam hal kepuasan kerja karyawan, masih perlu ditingkatkan karena sebagian karyawan masih tidak merasa puas dengan pekerjaannya, berhubungan dengan kurang penghargaan perusahaan terhadap pekerjaan karyawan. Kondisi ini menyebabkan prestasi kerja karyawan tidak maksimal, sebagaimana dilihat dari pencapaian target (rencana) kerja. Adanya sebagian karyawan yang mengundurkan diri serta pelaksanaan pekerjaan yang tidak maksimal menunjukkan kurangnya komitmen karyawan. Kurangnya komitmen karyawan terhadap pekerjaannya akan menurunkan produktivitasnya di dalam perusahaan.

Dalam hal komitmen karyawan yang rendah, terutama berhubungan dengan beberapa faktor kurang mendapat perhatian perusahaan, diantaranya adalah masa kerja yang tidak sesuai dengan promosi, di mana 
sebagian karyawan dengan masa kerja yang sudah cukup lama tidak mendapat promosi di dalam perusahaan. Demikian juga dengan Iklim Organisasi terutama dalam hal kebebasan mengembangkan kemampuan karyawan masih kurang karena sistem pekerjaan dalam perusahaan. Selain kedua faktor tersebut, komitmen karyawan juga berhubungan dengan karakteristik pribadi karyawan tersebut, dimana karakteristik pribadi ini berhubungan dengan keinginan dan harapan karyawan di dalam perusahaan. Dalam hal ini, semakin terpenuhi keinginan dan harapan karyawan di dalam perusahaan, maka komitmen karyawan akan semakin tinggi, dan dalam kenyataannya para karyawan sering merasa bahwa keinginan dan harapannya tidak terpenuhi oleh perusahaan.

Berdasarkan uraian di atas dapat dilihat bahwa fenomena tersebut menunjukkan adanya hubungan antara Iklim Organisasi, komitmen, dan kepuasan kerja dengan prestasi kerja karyawan. Penulis tertarik untuk dilakukan penelitian untuk mendapatkan bukti-bukti empiris mengenai pengaruh Iklim Organisasi, komitmen, dan kepuasan terhadap prestasi kerja karyawan, yang dilakukan di PT. XL Axiata Regional Sumatera di Padang.

\section{Tinjauan pustaka}

\subsection{Iklim Organisasi}

Menurut Purnomosidhi (1996), bahwa iklim organisasi adalah suatu kondisi atau suasana organisasi yang diciptakan oleh berbagai komponen yang membentuk suatu nilai kebijaksanaan dimana pelaksanaannya sesuai dengan kepentingan bersama. Selanjutnya dijelaskan pula bahwa iklim organisasi berpengaruh positif pada kinerja dan kepuasan kerja, sehingga semakin sesuai dan sehat suatu iklim organisasi akan semakin tinggi tingkat kepuasan kerja dan kinerja pegawai.

Owens (1995) mendefinisikan iklim organisasi sebagai studi persepsi individu mengenai berbagai aspek lingkungan organisasinya. Sementara Davis (1997) dalam Djatmiko (2005) mengemukakan pengertian iklim organisasi sebagai .The human environment within an organization.s employees do their work.. Pernyataan Davis tersebut mengandung arti bahwa iklim organisasi itu adalah yang menyangkut semua lingkungan yang ada atau yang dihadapi oleh manusia di dalam suatu organisasi tempat mereka melaksanakan pekerjaannya.

Stringer (2002) mendefinisikan iklim organisasi sebagai kualitas lingkungan internal organisasi yang secara relatif terus berlangsung, dialami oleh anggota organisasi, mempengaruhi perilaku mereka dan dapat dilukiskan dalam pengertian satu set karakteristik atau sifat organisasi. Lebih lanjut dinyatakan bahwa iklim organisasi merupakan suatu konsep yang melukiskan sifat subjektif atau kualitas lingkungan organisasi.

Definisi lain tentang iklim organisasi dikemukakan oleh Gilmer (1995) dalam Hoy dan Miskel (2001) yang menyebutkan bahwa iklim organisasi merupakan karakteristik yang membedakan satu organisasi dengan organisasi lainnya dan mempengaruhi orang-orang dalam organisasi tersebut. Sedangkan Steers menyebutkan bahwa iklim organisasi dapat dipandang sebagai kepribadian organisasi yang dicerminkan oleh anggota-anggotanya. Lebih lanjut Steers (2005) mengatakan bahwa iklim organisasi tertentu adalah iklim yang dilihat pekerjanya, tidak selalu iklim yang sebenarnya dan iklim yang muncul dalam organisasi merupakan faktor pokok yang menentukan perilaku pekerja.

Dari pengertian-pengertian yang dikemukakan tersebut jelas bahwa iklim organisasi berhubungan erat dengan persepsi individu terhadap lingkungan sosial organisasi yang mempengaruhi organisasi dan perilaku anggota organisasi. Hoy dan Miskel (2001) menyebutkan ada dua tipe iklim organisasi, yaitu iklim organisasi terbuka dan iklim organisasi tertutup. Pada iklim organisasi terbuka, semangat kerja karyawan sangat tinggi, dorongan pimpinan untuk memotivasi karyawannya agar berprestasi sangat besar; sedangkan rutinitas administrasi rendah, karyawan yang meninggalkan pekerjaan seperti bolos, izin dan sebagainya juga rendah; perasaan terpaksa untuk bekerja juga rendah. Sebaliknya, pada iklim organisasi yang tertutup, semangat kerja karyawan sangat rendah; dorongan pimpinan untuk memotivasi karyawannya berprestasi 
sangat rendah; sedangkan rutinitas administratif tinggi, karyawan yang meninggalkan pekerjaan tinggi; perasaan terpaksa untuk bekerja juga tinggi.

\subsection{Komitmen Karyawan}

Komitmen organisasi dapat didefinisikan sebagai .relative strength of an individual.s identification with an involvement in a particular organization. (Porter et al. dalam Prasetyono dan Kompyurini, (2007). Selanjutnya mendefinisikan komitmen sebagai:

1). Keyakinan dan penerimaan tujuan dan nilai organisasi.

2). Kemauan untuk berusaha atau bekerja untuk kepentingan organisasi.

3). Hasrat untuk menjaga keanggotaan organisasi.

Menurut Meyer (1993) dalam Prasetyono dan Kompyurini (2007), komitmen organisasi dibangun melalui identifikasi individual dengan tujuan organisasi (affective commitment) dan biaya terkait dengan tetap tinggalnya seseorang pada suatu organisasi (the .side-bet. theory atau continuance commitment) serta apa yang sebaiknya dilakukan (normatif commitment).

Komitmen organisasi adalah perasaan dan sikap para pekerja tentang keseluruhan organisasi (Riggio, 2000). Seseorang pekerja yang mempunyai perasaan positif terhadap keseluruhan organisasi kerja kelihatannya akan lebih sedikit absennya dalam bekerja dan sedikit yang meninggalkannya untuk bekerja pada organisasi lain dibandingkan jika pekerja mempunyai sikap perasaan negatif terhadap organisasinya.

Argyris dalam Sukarno dan Prasetyohadi (2004) membagi komitmen menjadi dua, yaitu komitmen internal dan komitmen eksternal. Komitmen internal merupakan komitmen yang berasal dari diri karyawan untuk menyelesaikan berbagai tugas, tanggung jawab dan wewenang berdasarkan pada alasan dan motivasi yang dimiliki. Komitmen eksternal dibentuk oleh Iklim Organisasi, yang muncul karena adanya tuntutan terhadap penyelesaian tugas dan tanggung jawab yang harus diselesaikan oleh para karyawan.

\subsection{Kepuasan Kerja}

Kepuasan kerja adalah suatu tingkatan emosi yang menyenangkan dan bersifat positif yang muncul atau dihasilkan dari penilaian terhadap suatu prestasi kerja atau pengalaman (Locke dalam Luthans, 2006). Sedangkan Davis (1996), memandang kepuasan kerja sebagai rasa senang seseorang dalam memandang pekerjaannya. Jadi, kepuasan kerja akan tercapai apabila terdapat kesesuaian antara pekerjaan yang dibebankan dengan keinginan individu pegawai.

Menurut Dole and Schroeder (2001), kepuasan kerja dapat didefinisikan sebagai perasaan dan reaksi individu terhadap lingkungan pekerjaannya. Dalam pernyataan tersebut mengandung makna bahwa kepuasan kerja merupakan suatu keadaan emosi yang positif atau dapat menyenangkan yang dihasilkan dari suatu penilaian terhadap pekerjaan atau pengalaman-pengalaman kerja seseorang.

Menurut Linz (2002), bahwa secara positif sikap terhadap kerja ada hubungan positif dengan kepuasan kerja. Pada dasarnya makin positif sikap kerja makin besar pula kepuasan kerja, untuk itu berbagai indikator dari kepuasan kerja perlu memperoleh perhatian khusus agar pekerja dapat meningkatkan kinerjanya. Pada umumnya seseorang merasa puas dengan pekerjaannya karena berhasil dan memperoleh penilaian yang adil dari pimpinannya.

\subsection{Prestasi Kerja}

Prestasi kerja atau prestasi kerja karyawan adalah hasil kerja atau kinerja yang dihasilkan oleh para pekerja dalam organisasi (Yousef, 2000). Prestasi kerja karyawan tidak hanya sekedar informasi 
tentang dapat dilakukannya promosi dan penetapan gaji bagi perusahaan. Tetapi yang lebih penting adalah bagaimana mengembangkan satu rencana untuk memperbaiki kemerosotan apa saja yang mungkin sudah digali oleh penilaian, dan mendorong hal-hal baik yang sudah dilakukan bawahan. Penilaian di sini dimaksudkan untuk memberikan satu peluang yang baik untuk meninjau rencana karir orang itu dilihat dari kekuatan dan kelemahan yang diperlihatkan. Akhirnya, semua itu dengan satu sasaran yaitu kebutuhan dan kepuasan pelanggan.

Prestasi kerja karyawan (employee performance) adalah tingkat terhadap mana para karyawan mencapai persyaratan-persyaratan dalam pekerjaan (Baron \& Gerald dalam Ruky, 2006). Sedang Ivancevich dan Matteson (1999) mendefinisikan sebagai hasil kerja karyawan yang diperoleh dari resultan/gabungan perilaku karyawan dan organisasi. Dari dua definisi di atas, prestasi kerja karyawan merupakan sesuatu yang penting bagi organisasi/perusahaan, tidak terkecuali perusahaan manufaktur.

Menurut Heneman, Schab dan Fossum dalam Istitimijati (1996) bahwa secara umum pengukuran prestasi kerja mencakup dua kegiatan. Pertama, identifikasi dimensi prestasi kerja yang mencakup semua unsur yang akan dievaluasi dalam pekerjaan masing-masing karyawan dalam suatu organisasi. Kedua, penetapan standar prestasi kerja. Berdasarkan pernyataan tersebut, untuk mengetahui prestasi kerja karyawan diperlukan tolok ukur meliputi: kuantitas, kualitas dan ketepatan waktu kerja.

Berdasarkan telaah pustaka yang telah dilakukan diatas, maka model pemikiran teoritis yang dikembangkan pada penelitian ini terlihat pada gambar berikut ini :

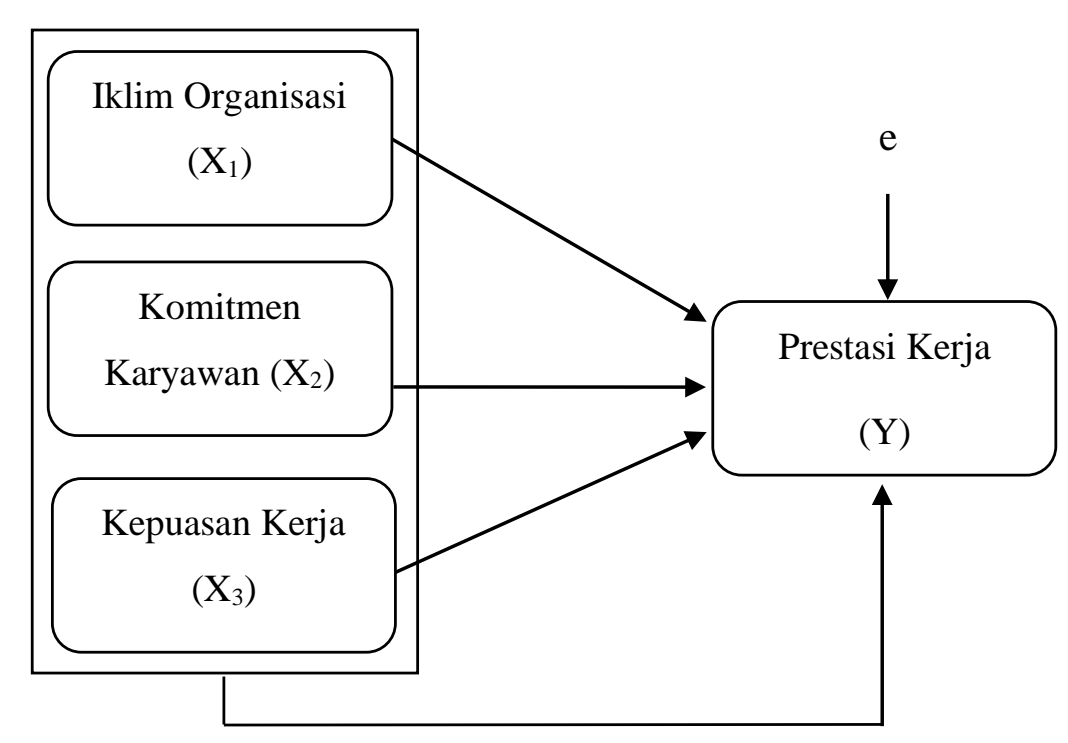

Gambar 2.1: Kerangka Konseptual

\section{Metode Penelitian.}

Penelitian ini dilakukan dengan menggunakan pendekatan survey. Menurut Arikunto (2005), .Pendekatan survey adalah kegiatan mengumpulkan data sebanyak - banyaknya mengenai fakta - fakta yang merupakan 
pendukung terhadap penelitian, dengan maksud untuk mengetahui status dan gejala. Singarimbun dan Effendi (1995) menyatakan bahwa, penelitian survey adalah penelitian yang mengambil sampel dari satu populasi dan menggunakan kuesioner sebagai alat pengumpulan data yang pokok. Sifat penelitian ini adalah explanatory. Menurut Sugiyono (2006), explanatory adalah penelitian yang bermaksud menjelaskan kedudukan variabel - variabel.

Yang diteliti serta hubungan antara satu variabel dengan variabel yang lain. Menurut Singarimbun dan Effendi (1995) bahwa penelitian penjelasan menyoroti hubungan antara variable - variabel penelitian dan menguji hipotesa yang telah dirumuskan sebelumnya.. Jenis penelitian adalah deskriptif kuantitatif yaitu untuk mengetahui dan menganalisis pengaruh Iklim Organisasi, komitmen karyawan dan kepuasan kerja terhadap prestasi kerja karyawani pada PT. XL Axiata Padang. Menurut Sugiyono (2006), penelitian deskriptif dilakukan untuk menjelaskan setiap variabel penelitian.

Metode yang digunakan dalam penelitian ini adalah metode survei. Metode Survei menurut Sugiyono (2009) adalah penelitian yang dilakukan pada populasi besar maupun kecil, tetapi data yang dipelajari adalah data dari sampel yang diambil dari populasi tersebut, sehingga dapat ditemukan kejadian-kejadian relatif, distributif dan hubungan antar variabel, sosiologis maupun psikologis. Sedangkan bentuk penelitiannya adalah Penelitian Deskriptif. Penelitian Deskriptif adalah mempelajari masalah masalah deskriptif dalam masyarakat, serta tata cara yang berlaku dalam masyarakat serta situasi-situasi tertentu, termasuk tentang hubungan kegiatan-kegiatan, sikap-sikap, pandangan, serta proses-proses yang sedang berlangsung dan pengaruh-pengaruh dari fenomena. Dalam penelitian ini, metode deskriptif bertujuan mengungkapkan atau menjelaskan karakteristik dari masing-masing variabel yang diteliti. Dalam penelitian survey hasil akhir hanya menjelaskan karakteristik variabel dengan variabel lainnya (secara parsial dan simultan). Dalam hal teknik pengumpulan data menurut kegiatan yang dilakukan maka teknik yang digunakan adalah Survei Lapangan (field survei). Survei lapangan dilakukan dengan cara pengisian kuisioner oleh karyawan PT. XL Axiata Padang. Kuesioner yang diberikan adalah kuesioner yang telah ditentukan jawabannya, responden hanya memilih satu dari beberapa jawaban yang tersedia.

\section{Teknis Analisis Data dan Uji Hipotesis}

Teknik analisis data dalam penelitian ini menggunakan regresi linear berganda, yaitu suatu pendekatan yang bertujuan untuk melihat sejauh mana kemampuan dari semua variabel bebas atau independen yang meliputi Iklim Organisasi $\left(\mathrm{X}_{1}\right)$, komitmen karyawan $\left(\mathrm{X}_{2}\right)$ dan kepuasan kerja $\left(\mathrm{X}_{3}\right)$ dalam menjelaskan atau mempengaruh variabel terikat atau dependen yang dalam hal ini adalah variabel prestasi kerja (Y). Namun sebelum dilakukan analisis regresi linear berganda, telah dilakukan pengujian persyaratan atau asumsi klasik yang meliputi uji normalitas, multikolinearitas, uji autokorelasi, dan uji homogenitas. Dimana secara keseluruhan temuan menunjukan model yang dibangun dapat memenuhi model yang layak atau dapat menjelaskan kerangka konseptual yang telah dibentuk dalam menjelaskan hipotesis penelitian.

Berikut ringkasan hasil pengujian regresi, sebagaimana yang tampak pada tabel di bawah ini :

\section{Tabel.1 Hasil Nilai Koefisien Regresi}

\begin{tabular}{|c|l|r|r|r|r|c|}
\hline \multirow{2}{*}{ Model } & \multirow{2}{*}{ Coefisient } & \multicolumn{2}{|c|}{$\begin{array}{c}\text { Unstandardized } \\
\text { Coefficients }\end{array}$} & $\begin{array}{c}\text { Standardized } \\
\text { Coefficients }\end{array}$ & \multirow{2}{*}{$\mathrm{t}$} & \multirow{2}{*}{ Sig. } \\
\cline { 3 - 6 } & & \multicolumn{1}{c|}{$\begin{array}{c}\text { Std. } \\
\text { Error }\end{array}$} & Beta & & \\
\hline 1 & (Constant) & 1.961 & 1.161 & & 1.689 & .038 \\
\hline & Iklim Organisasi & .226 & .080 & .171 & 2.823 & .006 \\
\hline & Komitmen Karyawan & .499 & .081 & .518 & 6.175 & .000 \\
\hline & Kepuasan Kerja & .312 & .076 & .319 & 4.119 & .000 \\
\hline & F & & & 125.917 \\
\hline
\end{tabular}




\section{Sumber : Hasil Pengolahan data SPSS}

Berdasarkan hasil nilai koefisien regresi yang terlihat pada tabel di atas, secara keseluruhan semua variabel independen yang meliputi Iklim Organisasi $\left(\mathrm{X}_{1}\right)$, komitmen karyawan $\left(\mathrm{X}_{2}\right)$ dan kepuasan kerja $\left(\mathrm{X}_{3}\right)$ dapat mempengaruhi variabel prestasi kerja $(\mathrm{Y})$ sebagai variabel dependen. Ini dapat dilihat dari nilai signifikan masing-masing variabel independen yang nilainya jauh dibawah kesalahan menolak data atau $\alpha=5 \%$.

Dengan demikian, dapat dibentuk persamaan regresi linear berganda sebagai berikut:

$\mathrm{Y}=1,961+0,226 \mathrm{X} 1+0,499 \mathrm{X} 2+0,312 \mathrm{X} 3$

\section{HASIL PENELITIAN DAN PEMBAHASAN}

\subsection{Pengaruh Iklim Organisasi Terhadap Prestasi Kerja Karyawan}

Berdasarkan hasil hipotesis ditemukan bahwa variabel Pengaruh secara Parsial Iklim Organisasi Terhadap Prestasi Kerja Karyawan. Berdasarkan hasil analisis terdapat pengaruh yang signifikan antara Pengaruh Iklim Organisasi terhadap Prestasi Kerja Karyawan pada PT. XL Axiata Padang. Hal ini dibuktikan dengan melihat nilai signifikan probability yaitu $0,000<\alpha$ yaitu 0,000 artinya signifikan. Kontribusi variabel Pengaruh Iklim Organisasi terhadap variabel Prestasi Kerja Karyawan adalah 0,453 atau 45,3\%. Artinya Pengaruh Iklim Organisasi yang baik dapat meningkatkan Prestasi Kerja Karyawan pada PT. XL Axiata Padang Selain itu juga didapat nilai koefisien dari variable Pengaruh Iklim Organisasi sebesar 0,881. Artinya jika terjadi peningkatan nilai Pengaruh Iklim Organisasi sebesar satu satuan maka akan meningkatkan Prestasi Kerja sebesar 0,881 satuan. Demikian juga sebaliknya jika terjadi penurunan nilai Pengaruh Iklim Organisasi sebesar satu satuan maka akan menurunkan Prestasi Kerja sebesar 0,881 satuan.

\subsection{Pengaruh Komitmen Karyawan Terhadap Prestasi Kerja Karyawan}

Pengaruh Komitmen Pegawai Terhadap Prestasi Kerja dari hasil analisis dapat dilihat bahwa terdapat pengaruh yang signifikan antara Komitmen Pegawai terhadap Prestasi Kerja PT. XL Axiata Padang. Hal ini dibuktikan dengan melihat nilai signifikan probability yaitu $0,000<\alpha$ yaitu 0,05 artinya signifikan. Kontribusi variabel Komitmen Pegawai terhadap variabel Prestasi Kerja Pegawai diketahui sebesar 0,842 atau 84,20\%. Ini berarti Komitmen Pegawai yang baik dapat meningkatkan Prestasi Kerja pada PT. XL Axiata Padang Selain itu juga didapat nilai koefisien dari variabel Komitmen Pegawai sebesar 0,995 Artinya jika terjadi peningkatan nilai Komitmen Pegawai sebesar satu satuan maka akan meningkatkan Prestasi Kerja sebesar 0,879 satuan. Demikian juga sebaliknya jika terjadi penurunan nilai Komitmen Pegawai sebesar satu satuan maka akan menurunkan Prestasi Kerja sebesar 0,879 satuan.

\subsection{Pengaruh Kepuasan Kerja Terhadap Prestasi Kerja Karyawan}

Pengaruh Kepuasan Kerja Terhadap Prestasi Kerja dari hasil analisis dapat dilihat bahwa terdapat pengaruh yang signifikan antara Kepuasan Kerjavterhadap Prestasi Kerja PT. XL Axiata Padang. Hal ini dibuktikan dengan melihat nilai signifikan probability yaitu $0,000<\alpha$ yaitu 0,05 artinya signifikan. Kontribusi variabel Kepuasan Kerja terhadap variabel Prestasi Kerja diketahui sebesar 0,763 atau 76,3\%. Ini berarti Kepuasan Kerja yang baik dapat meningkatkan Prestasi Kerja PT. XL Axiata Padang. Selain itu juga didapat nilai koefisien dari variabel Kepuasan Kerja sebesar 0,848 Artinya jika terjadi peningkatan nilai Kepuasan Kerja sebesar satu satuan maka akan meningkatkan Prestasi Kerja sebesar 0,848 satuan. Demikian juga sebaliknya jika terjadi penurunan nilai Kepuasan Kerjas ebesar satu satuan maka akan menurunkan Prestasi Kerja Pegawai sebesar 0,848 satuan. 


\subsection{Pengaruh Iklim Organisasi, Komitmen Karyawan dan Kepuasan Kerja secara simultan Terhadap Prestasi Kerja Karyawan}

Penilaian pengaruh secara bersama - sama atau simultan dari semua variable yaitu Iklim Organisasi, Komitmen Karyawan dan Kepuasan Kerja berpengaruh signifikan terhadap Prestasi Kerja. Berdasarkan hasil analisis dan uji hipotesis nilai signifikan probability $0,000<\alpha$ yaitu 0,05 , artinya signifikan, ini berarti Pengaruh Iklim Organisasi, Komitmen karyawan Serta Kepuasan Kerjas secara bersama-sama berpengaruh terhadap Prestasi Kerja Karyawan. Kontribusi Pengaruh Iklim Organisasi, Komitmen Karyawan serta Kepuasan Kerja terhadap Prestasi Kerja sebesar 83,30 \% sedangkan 16,70 \% ditentukan oleh faktor lain. faktor -faktor lain itu bisa berupa pengembangan karir yang tepat dan sesuai dengan keahlian, kepuasan karyawan kemudian sifat pekerjaan, Komitmen Karyawan, dll. Jadi dapat disimpulkan bahwa Pengaruh Iklim Organisasi, Komitmen Karyawan Serta Kepuasan Kerja Karyawan pada PT. XL Axiata Padang. Selain itu nilai konstanta yang didapat dari hasil analisis regresi linier berganda adalah 1,961, artinya jika segala sesuatu pada variabel-variabel independent dianggap konstan maka nilai dari Prestasi Kerja Karyawan adalah 1,961.

\section{KESIMPULAN}

Berdasarkan hasil penelitian yang dikemukakan pada bab sebelumnya maka dapat disimpulkan beberapa hal penting dalam penelitian ini yaitu:

1. Secara parsial sumbangan Pengaruh Iklim Organisasi terhadap Prestasi Kerja adalah sebesar 45,3 \%. Artinya bahwa Pengaruh Iklim Organisasi berpengaruh terhadap Prestasi Kerja. Dengan meningkatnya Iklim Organisasi maka akan dapat menentukan Prestasi Kerja dengan meningkatkan keharmonisan dalam bekrja maka kualitas hasil kerja meningkat. Disarankan kepada karyawan dalam menjalankan tugas memelihara dan meningkatkan Iklim Organisasi, karena Iklim Organisasi berpengaruh secara positif dan signikan terhadap terhadap Prestasi Kerja maka perlu kesadaran semua pihak pada perusahaan, termasuk pimpinan harus memiliki perhatian terhadap peningkatan kondisi harmonisasi diantara karyawan pada bidang masing-masing

2. Kontribusi Komitmen Karyawan terhadap Prestasi Kerja adalah sebesar 84,20 \%. Artinya bahwa Komitmen karyawan berpengaruh terhadap Prestasi Kerja. Karena Komitmen menunjukkan loyalitas oleh karyawan dalam menjalankan tugas pada suatu lembaga. Sedangkan Kepuasan Kerja terhadap Prestasi Kerja karyawan kontribusinya adalah sebesar 76,3 \%. Artinya bahwa Kepuasan Kerja berpengaruh terhadap Prestasi Kerja. Secara umum pelaksanaan Pengaruh Komitmen adalah gambaran loyalitas yang dimiliki karyawan dengan menunjukkan prilaku yang memihak perusahaan. Dengan demikian semua karyawan perlu mempertahankan komitmen yang sudah terbentuk dilingkungan perusahaan.

3. Kepuasan Kerja diperlukan agar karyawan merasa diperhatikan maka pimpinan perlu memberikan perhatian terhadap kebutuhan-kebutuhan yang diharapkan karyawan, sehingga tercipta keharmonisan karyawan dalam menjalankan tugas, serta akan dapat mengeluarkan seluruh potensi yang ada dalam menjalankan tugasnya.

4. Secara simultan sumbangan Iklim Organisasi, Komitmen Karyawan, Serta Kepuasan Kerja terhadap Prestasi Kerja adalah sebesar 83,30 \%. Artinya bahwa Iklim Organisasi, Komitmen Karyawan dan Kepuasan Kerja berpengaruh terhadap Prestasi Kerja. Dengan kata lain bahwa Prestasi Kerja PT. XL Axiata Padang dapat dipengaruhi oleh Iklim Organisasi, Komitmen Karyawan dan Kepuasan Kerja secara bersama-sama. Sedangkan untuk dapat mewujudkan hasil 
yang dilakukan oleh karyawan lebih baik, maka dituntut peningkatan kompetensi dengan Pendidikan dan Pelatihan, yang lebih baik untuk mencapai tujuan organisasi atau kelompok.

\section{DAFTAR PUSTAKA}

1) Arikunto, Suharsimi. 2002. Prosedur Penelitian, Suatu Pendekatan Praktek. Rhineka Cipta. Jakarta.

2) Davis, Keith. 1997. Organizational Behavior. Mc Graw Hill Book. New York.

3) Djatmiko, Yayat H. 2005. Perilaku Organisasi. Alfabeta, Bandung.

4) Gitosudarmo, I dan Sudita I.N. 2005. Perilaku Keorganisasian. Edisi Pertama BPFE.Yogyakarta.

5) Gouzaly, Saydam. 2000. Manajemen Sumber Daya Manusia. Gunung Agung. Jakarta.

6) Hoy, Wayne K., Cecil G. Miskel. 2001. Educational Administration: Theory, Research, and Practice. McGraw-Hill, Singapore

7) Linz, Susan J. 2002. Job Satisfaction Among Russian Workers. William Davidson Institute Working Paper. Reseacrh Feelow Wlliam Davidson Institute. University of Michigan.

8) Luthans, Fred. 2006. Perilaku Organisasi. Edisi Sepuluh. Andi. Yogyakarta.

9) Mangkunegara, Anwar Prabu, (2000), Manajemen Sumber Daya Manusia Perusahaan, Bandung : PT Remaja Rosdakarya.

10) Mangkunegara, Anwar Prabu, (2009), Evaluasi Kinerja SDM, Bandung : Refika Aditama.

11) Meyer, J.P, Natalie.J.Allen, Catherine.A.Smith, 1993, Commitment to Organization and Occupation: Extensions and Test of Three Companent Conceptuzation, Journal of af applied Psycology.vol 78.No.4.

12) Owens, Robert G. 1995. Organizational Behavior in Education. Allyn and Bacon. Boston. Practice. McGraw-Hill, Singapore.

13) Prasetyono dan Nurul Kompyurini. 2007. Analisis Kinerja Rumah Sakit Daerah dengan Pendekatan Balanced Scorecard Berdasarkan Komitmen Organisasi,Pengendalian Intern dan Penerapan Prinsip- $\quad$ prinsip Good Corporate Governance (GCG) (Survei pada Rumah Sakit Daerah di Jawa.

14) Steers, 2005, Efektifitas Organisasi, Erlangga, Jakarta.

15) Sugiyono, (2006), Metode Penelitian Kuantitatif, Kualitatif dan R\&D, (Edisi Kedelapan), Bandung : Alfabeta.Hasibuan, Malayu SP. 2005. Manajemen Sumber Daya Manusia. Edisi Revisi. Bumi Aksara. Jakarta. 